\title{
33. Implication of Local Flow in Western Java Area for Air Pollution Transport in Jakarta, Indonesia: End of Rainy Season ジャワ島西部の局地風がジャカルタの大気污染に与え得る影響 : 雨季の終わり
}

\author{
アセップ ソフィアン*。北田敏廣*。倉田 学児 * \\ Asep SOFYAN*, Toshihiro KITADA*, Gakuji KURATA*
}

\begin{abstract}
Western Java area has been numerically investigated using PSU-NCAR MM5. Mesoscale numerical simulation was performed under the synoptic scale meteorology by ECMWF data with a resolution of $0.5^{0} \mathrm{X} 0.5^{0}$. Five days long simulation on 4-9 March 2001 was carried out. During this period, the quite strong sea breeze developed on 5 and 6 March. On March 6, 2001, at 1300 LST, the sea breeze penetrated to around $20 \mathrm{~km}$ from the coast of Jakarta. In this season, over Java area a synoptic scale convergence line is formed by WSW and NW winds. This synoptic WSW wind blowing over Java tends to prohibit inlandward advancement of the sea breeze. Depth of the sea breeze, on 6 Mar 2001 at $1200,1300,1400$, and 1500 LST was $0.5,0.8,0.4$, and $0.2 \mathrm{~km}$, respectively; because of subsidence behind the convergence line by the synoptic WSW wind and the sea breeze from Java sea, upper part of the sea breeze layer was warmed after 1500 LST and thus the depth of the sea breeze was suppressed. Predicted near-surface wind at 4-9 March 2001 appears dominantly with westerly wind. In mountain area, wind direction was affected by a mountain wave. Highpressure system tends to be formed to the northeast of the Sunda street because of the topography. Then this highpressure system in turn generates dry stable layer over Jakarta at 2,000-4,000 m height and may suppress vertical diffusion of pollutants over Jakarta.
\end{abstract}

KEYWORDS: Jakarta, air pollution, local flow, sea breeze, high pressure system

\section{Introduction}

Jakarta city, tenth most populous city in the world, has experienced serious air pollution problems associated with the use of energy in the transport, domestic, and industrial sectors. Concentrations of street level air pollution along major roads in Jakarta have reached hazardous levels. Air quality in Jakarta is severely degraded. The amount of pollutants emitted by motor vehicles, industry and domestic activities is also increasing.

It is well known that meteorological conditions in a region often play a dominant role in building up severe air pollution. Thus our primary interest in this study is to evaluate the meteorological condition over western Java area, especially Jakarta city. For that reason, numerical simulation of the meteorology over western Java area was performed with the PSU-NCAR MM5 within the frame of meteorology in larger scale provided by ECMWF data with a resolution of $0.5^{0} \times 0.5^{0}$. Five days long simulation on 4-9 March 2001 was carried out. The objective of the simulation was to understand the mechanism of local flows and to generalize their characteristic interactions.

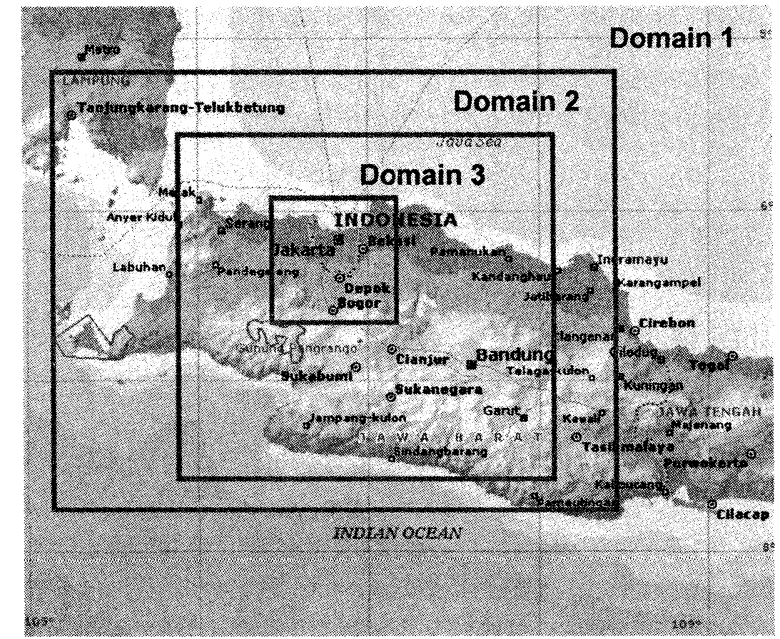

Fig. 1 The domain 1, 2, and 3 have $9 \mathrm{~km}, 3 \mathrm{~km}$, and $1 \mathrm{~km}$ grid size, respectively.

*Department of Ecological Engineering, Toyohashi University of Technology, Toyohashi, Japan 
The domain system used in this calculation consists of a triply nested two-way interacting mesh. Domain 1 have $50 \times 37$ horizontal grids points, domain $2,73 \times 73$ grids point, and domain $3,82 \times 82$ grids points. Each domain has 23 vertical grid points. The domain 1,2, and 3 have $9 \mathrm{~km}, 3 \mathrm{~km}$, and $1 \mathrm{~km}$ grid size respectively; i.e., coarse, fine, and finest grid. Latitude and longitude at the southwest and northeast corners of domain 1 are $8^{0} \mathrm{~S}, 105^{\circ} \mathrm{E}$ and $5^{\circ} \mathrm{S}, 109^{\circ} \mathrm{E}$, respectively. Figure 1 illustrates the domain system.

It is well known that ambient wind and land-sea temperature difference are two critical factors in the development of sea breezes (Simpson, 1994). The low-level mean flow over Jakarta is mainly governed by monsoon circulation with a distinct reversal of zonal wind from predominantly easterly in the dry season to westerly in the rainy season. It is found that the sea breeze develops well during the dry season (Hadi et al., 2001). However, nature and mechanism of sea breeze in the late rainy season is not well understood. Thus we focused on a late rainy season, 4-9 March 2001. Fig. 2 illustrates predicted near-surface wind over western Java area at 4 and 5 Mar 2001. During this period, in the rainy season, the surface wind pattern over the area appears dominantly with westerly wind.
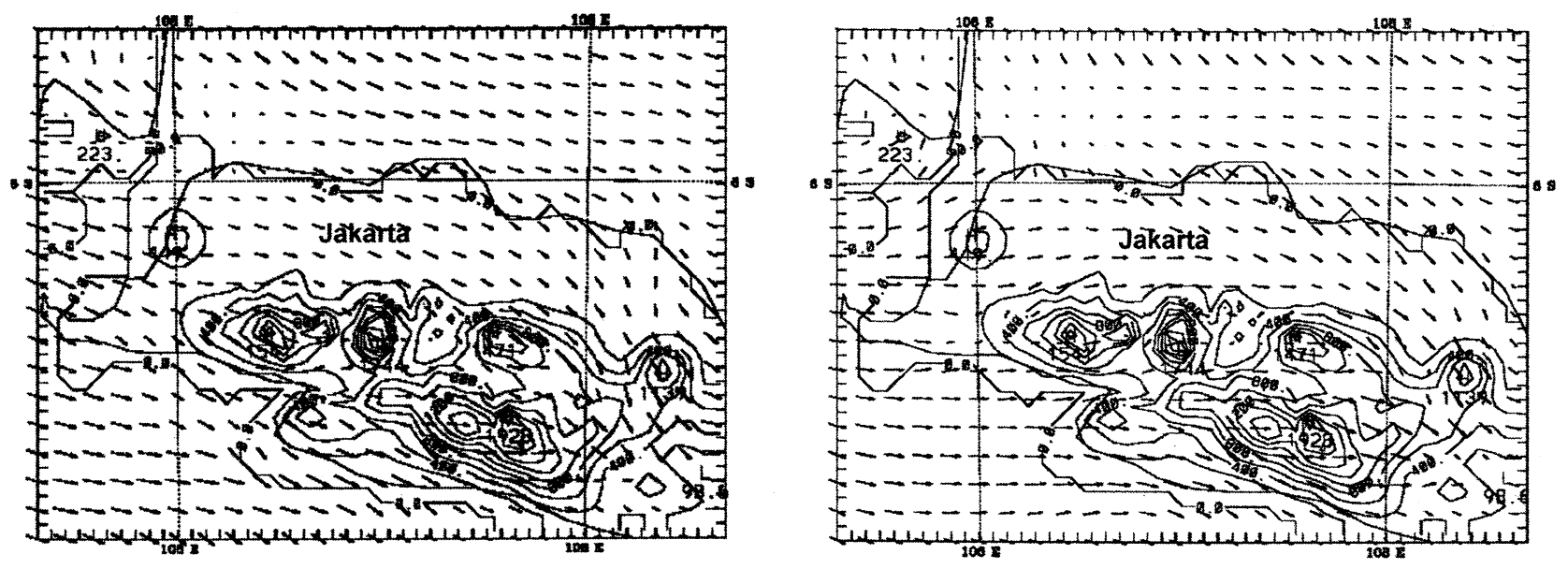

Fig.2. Predicted near-surface wind over western Java area at (a) 4 Mar 2001, 1200 LST and (b) 5 Mar 2001, 1300 LST. Contour shows terrain height interval of $200 \mathrm{~m}$.

Land-sea temperature difference in Jakarta area at 4-9 March 2001 is shown in Fig. 4; the location of sea surface is $5.8^{0} \mathrm{~S}-6.1^{\circ} \mathrm{S}$ and land is $6.2^{0} \mathrm{~S}-6.6^{\circ} \mathrm{S}$ (Fig. 3a).
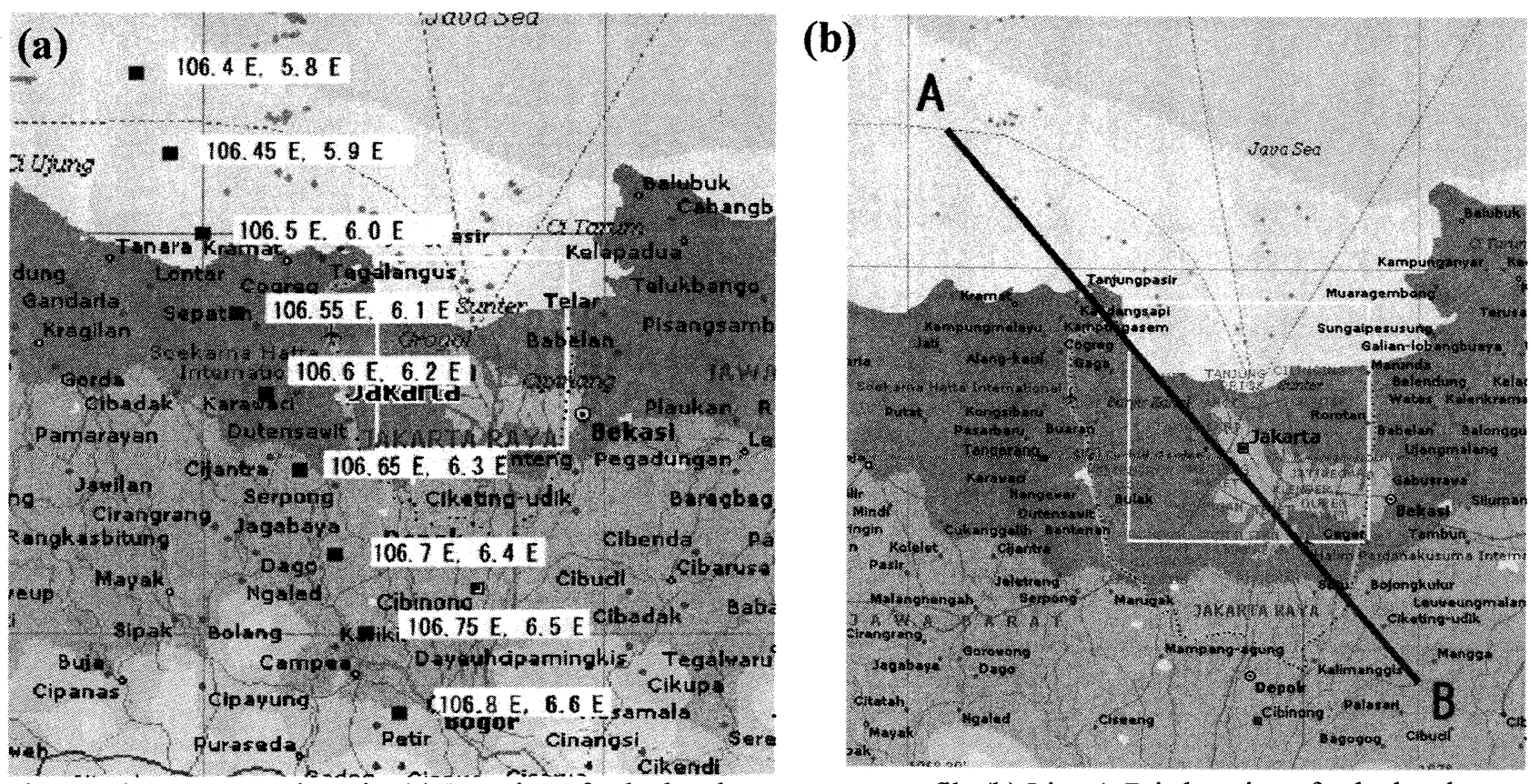

Fig. 3 Jakarta area, Indonesia. (a) Location of calculated temperature profile (b) Line A-B is location of calculated vertical cross section of potential temperature (Fig. 5). 
In Fig. 4, at 5 and 6 March, land-sea temperature difference larger than at 4, 7, and 8 March (Fig. 4). In Fig. 5 , the sea breeze at 5 and 6 March are quite strong and on 7 and 8 March are very weak. This condition agrees with the fact that sea breeze circulation is driven by daytime heating contrasts between land and water surfaces (see Fig.4).

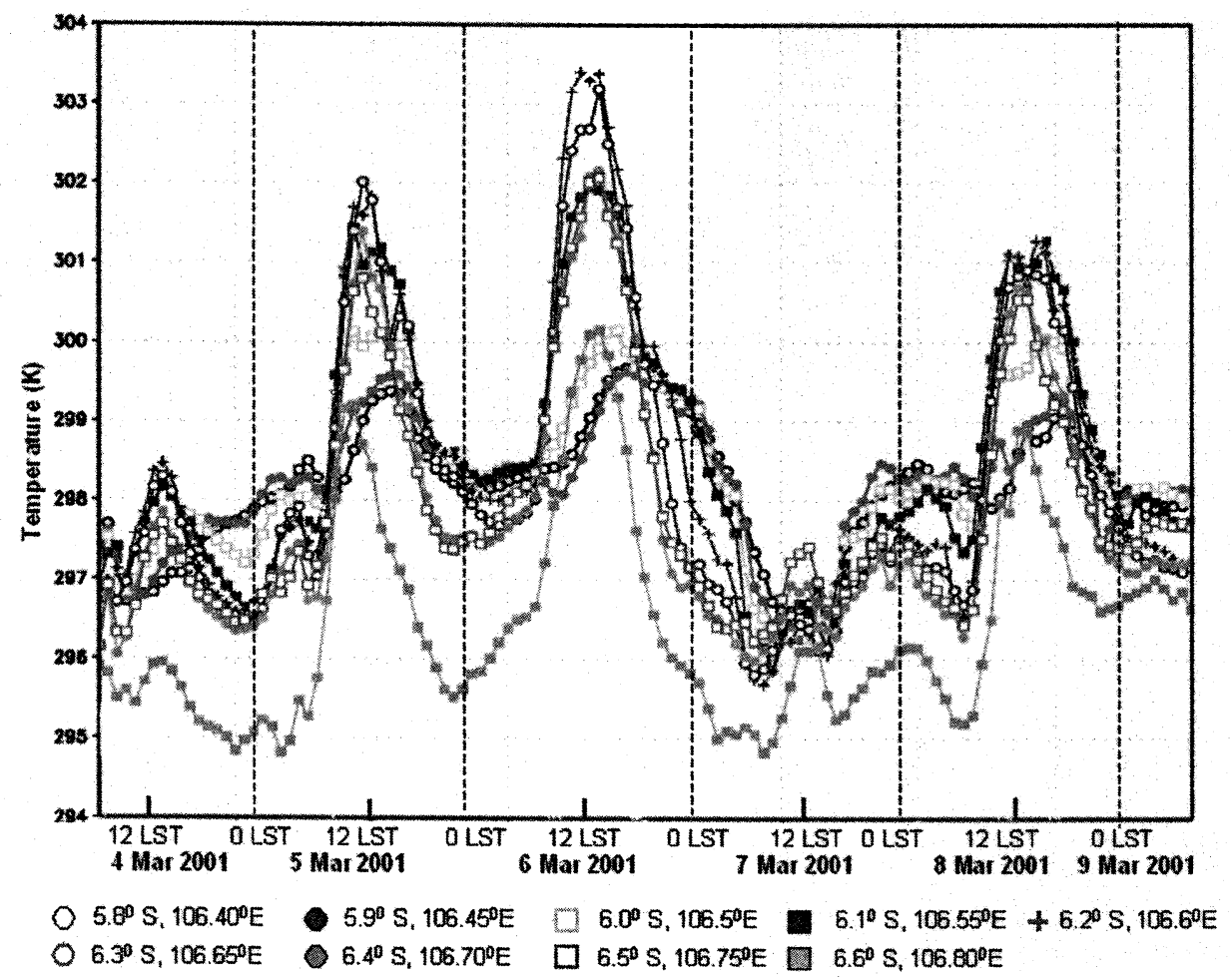

Fig. 4 Temperature profile in Jakarta area at 4-9 March 2001.

(a) March 5.2001

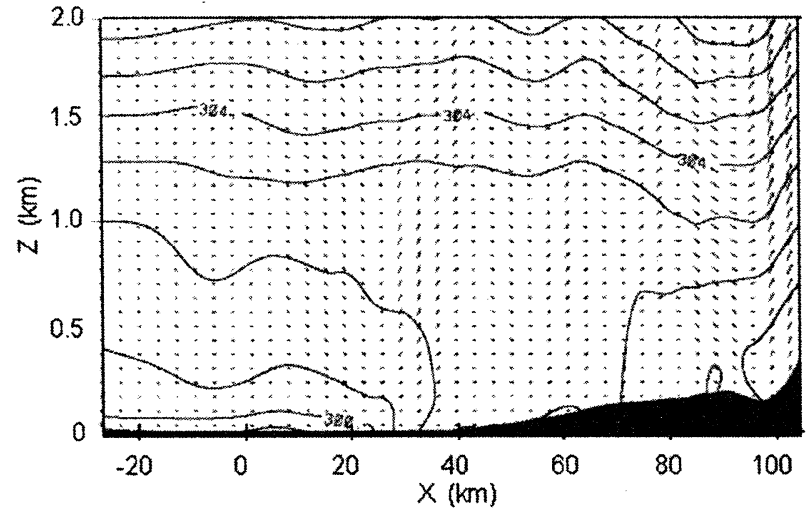

(c) March 7.2001

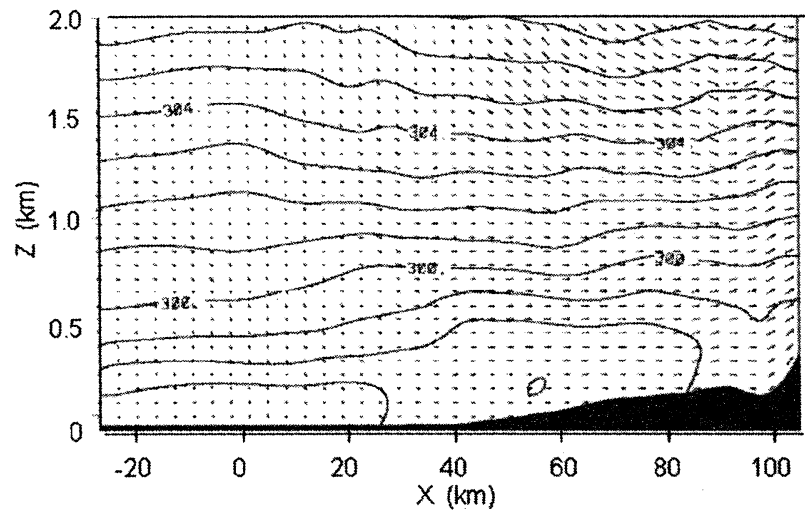

(b) March 6. 2001 $\theta \quad(\mathrm{K})$

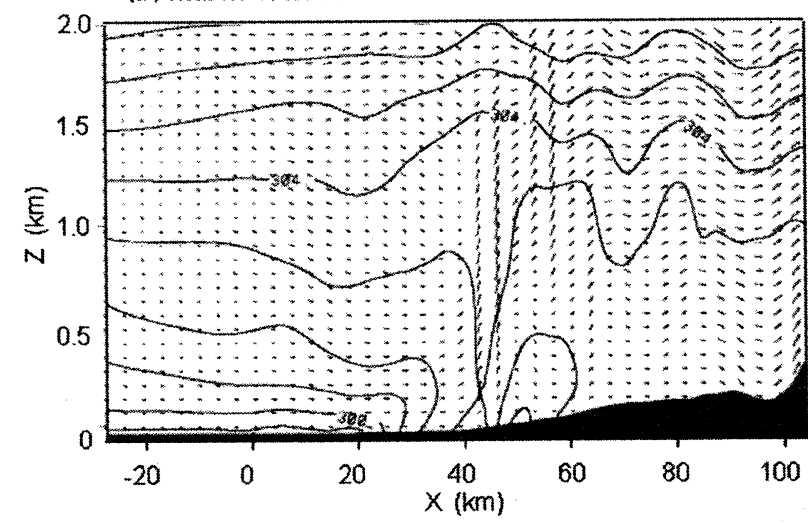

(d) March 8.2001

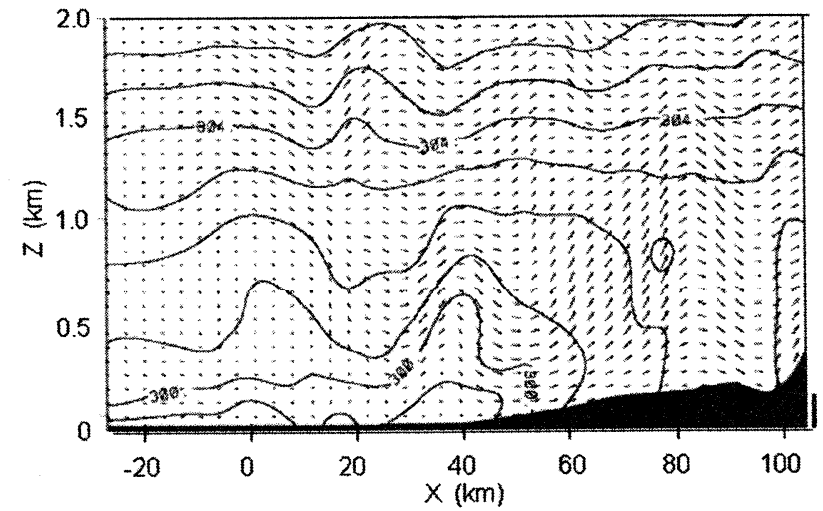

Fig. 5 Vertical cross section of potential temperature in Jakarta area at 5-8 March 2001 at 1300 LST (a) 5 March, (b) 6 March, (c) 7 March, and (d) 8 March. 

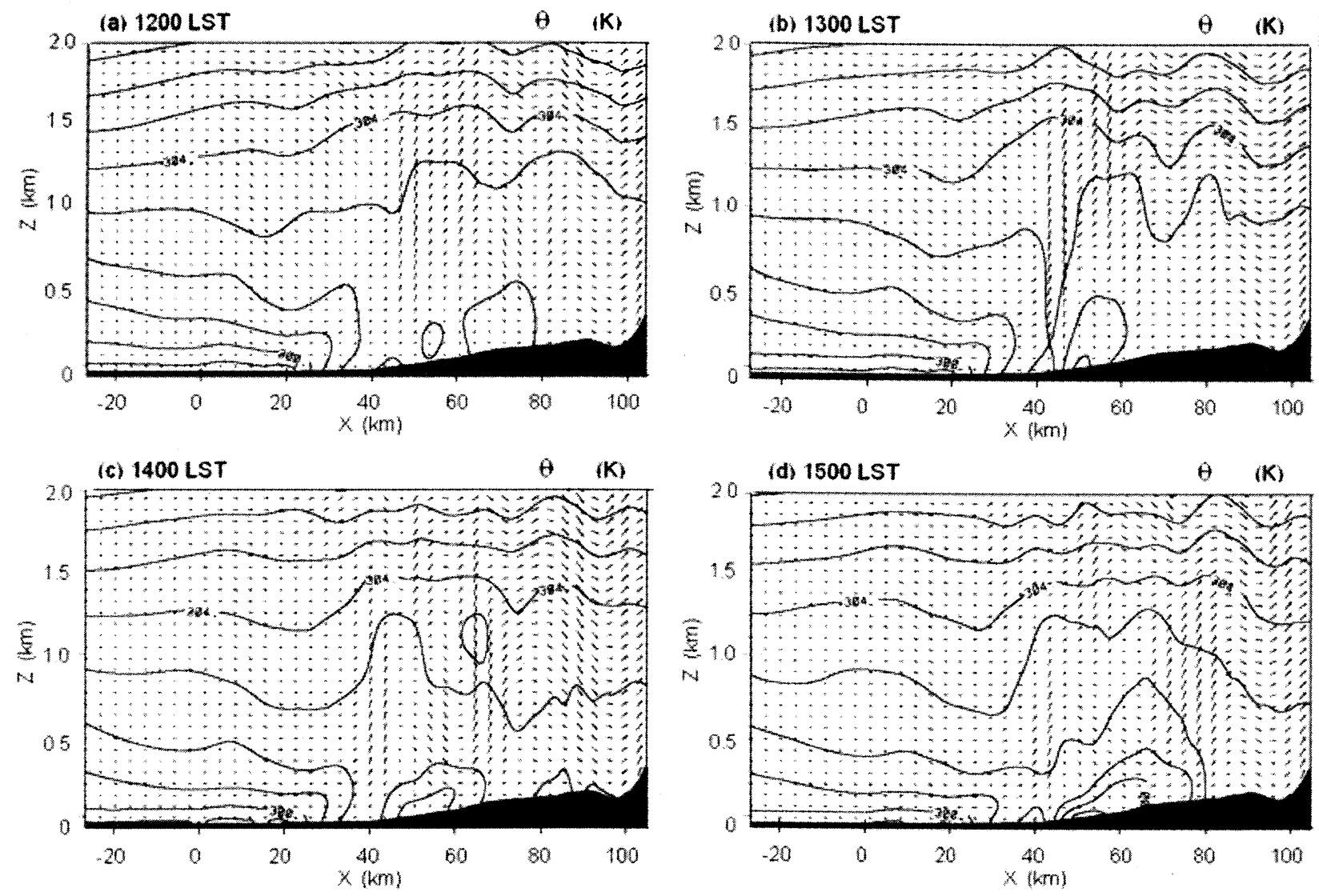

Fig.6 Vertical cross section of potential temperature in Jakarta area at March 6, 2001 (a) 1200 LST, (b) 1300 LST, (c) 1400 LST, and (d) 1500 LST.
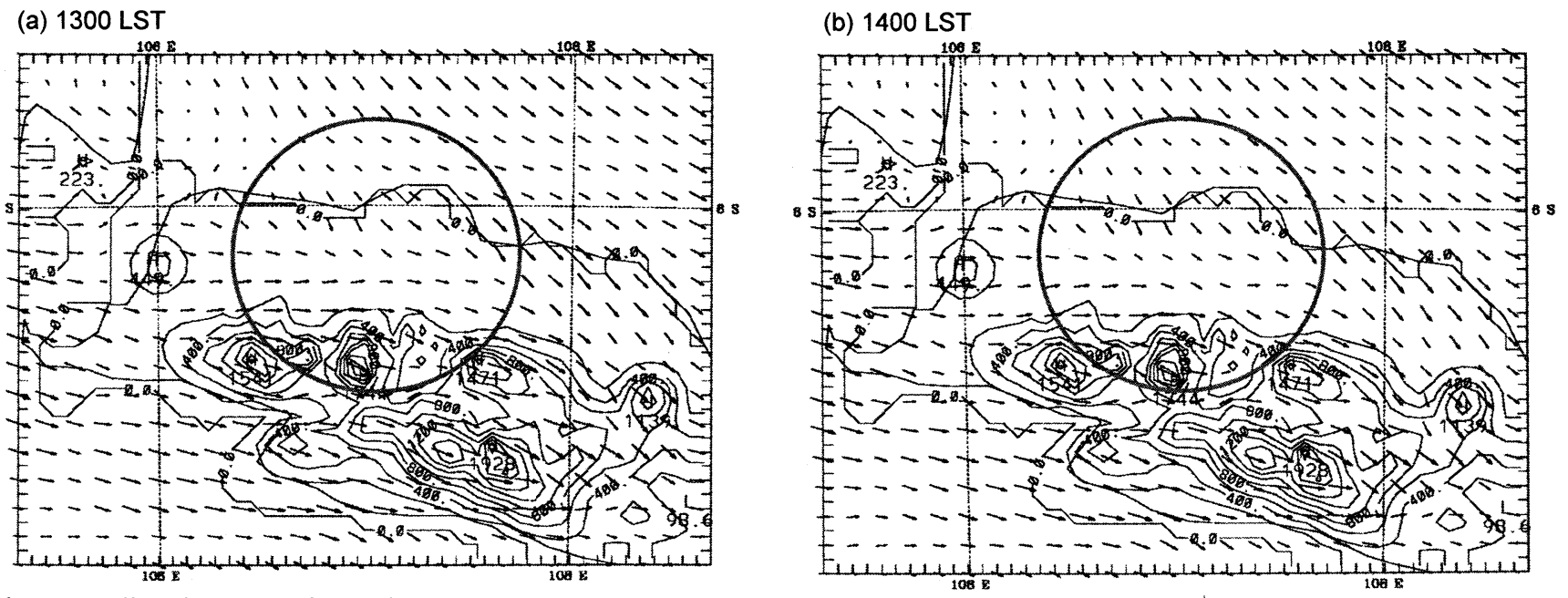

Fig. 7 Predicted near-surface wind over western Java area on 6 Mar 2001 at (a) 1300 LST, and (b) 1400 LST. Contour shows terrain height interval of $200 \mathrm{~m}$.

As shown in Fig. 5, the sea breeze developed on 5 and 6 March. On March 6, 2001 (Fig.6), the sea breeze arrived between 1200 and $1300 \mathrm{LST}$, which penetrated to around $20 \mathrm{~km}$ from the coast of Jakarta. In this season, over Java area a synoptic scale convergence line is formed by WSW and NW winds. This synoptic WSW wind blowing over Java tends to prohibit inlandward further advancement of the sea breeze (Fig. 7). Depth of the sea breeze, on 6 Mar 2001 at 1200, 1300, 1400, and 1500 LST was 0.5, 0.8, 0,4, and 0,2 km, respectively; because of subsidence behind the convergence line by the synoptic WSW wind and the sea breeze from Java sea, upper part of the sea breeze layer was warmed after 1500 LST and thus the depth of the sea breeze was suppressed. 
(a) 106.7 E, 6.24s

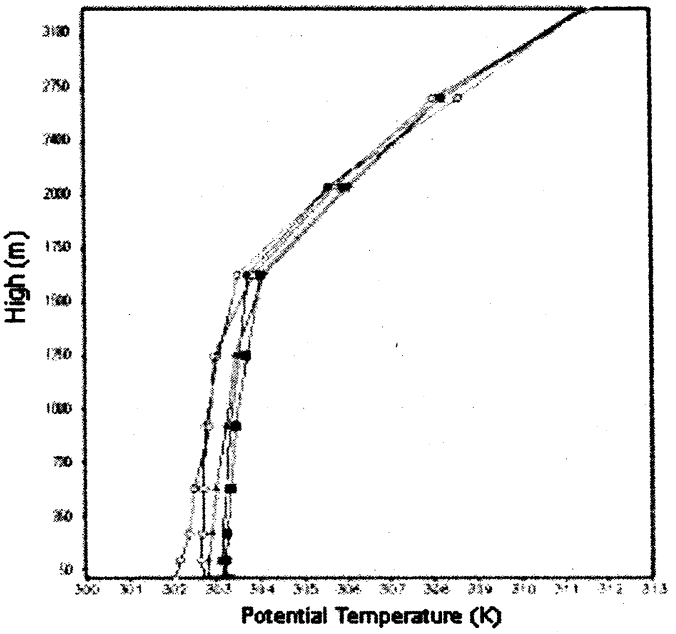

(c) $106.8^{\circ} \mathrm{E}, 6.2^{\circ} \mathrm{S}$

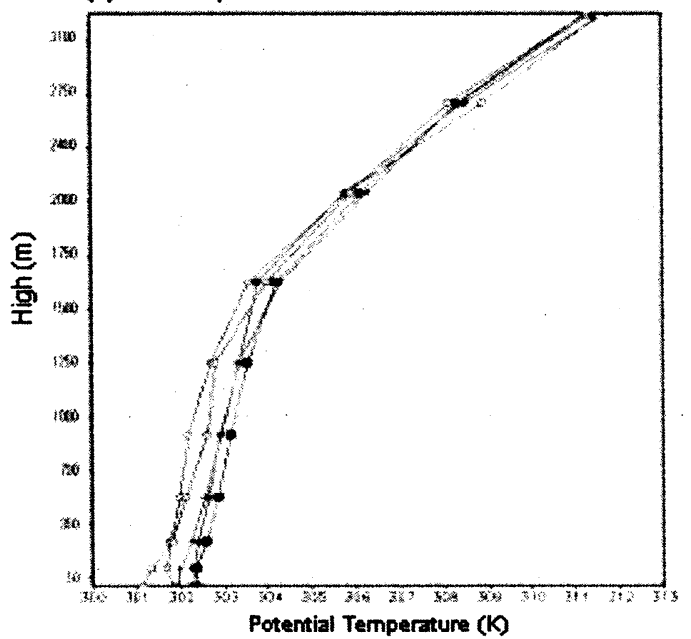

O 1100 LST (b) $106.8^{4} \mathrm{E}, 6.3^{4} \mathrm{~S}$

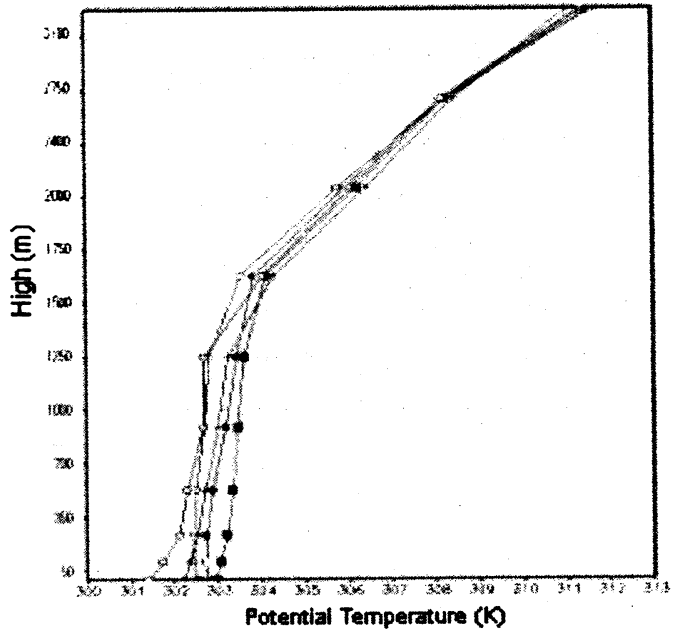

(d) $107.0^{\circ} \mathrm{E}, 6.2^{\circ} \mathrm{S}$

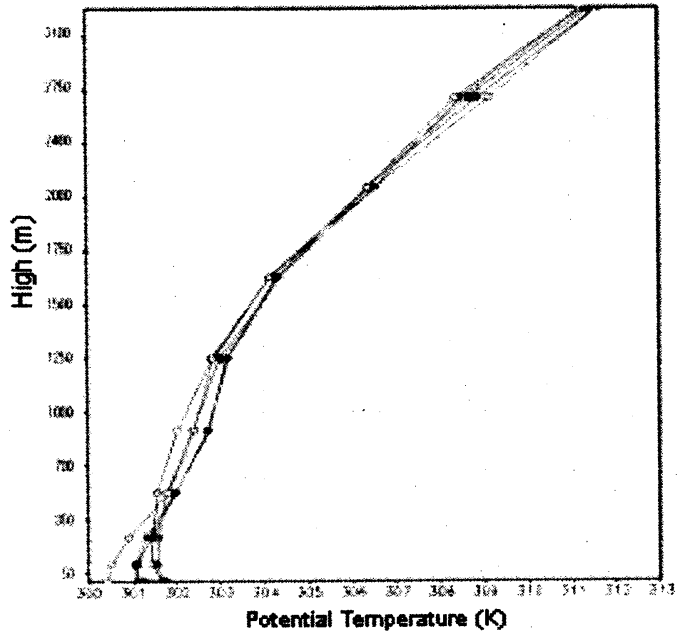

1400 LST + 1500 LST O 1600 LST

Fig. 8 Calculated potential temperature profile over Jakarta area on 6 Mar 2001 at (a) $106.7^{0} \mathrm{E}, 6.2^{\circ} \mathrm{S}$ (b) $106.8^{0} \mathrm{E}, 6.3^{\circ} \mathrm{S}$ (c) $106.8^{\circ} \mathrm{E}, 6.2^{\circ} \mathrm{S}$ and (d) $107.0^{\circ} \mathrm{E}, 6.2^{\circ} \mathrm{S}$.

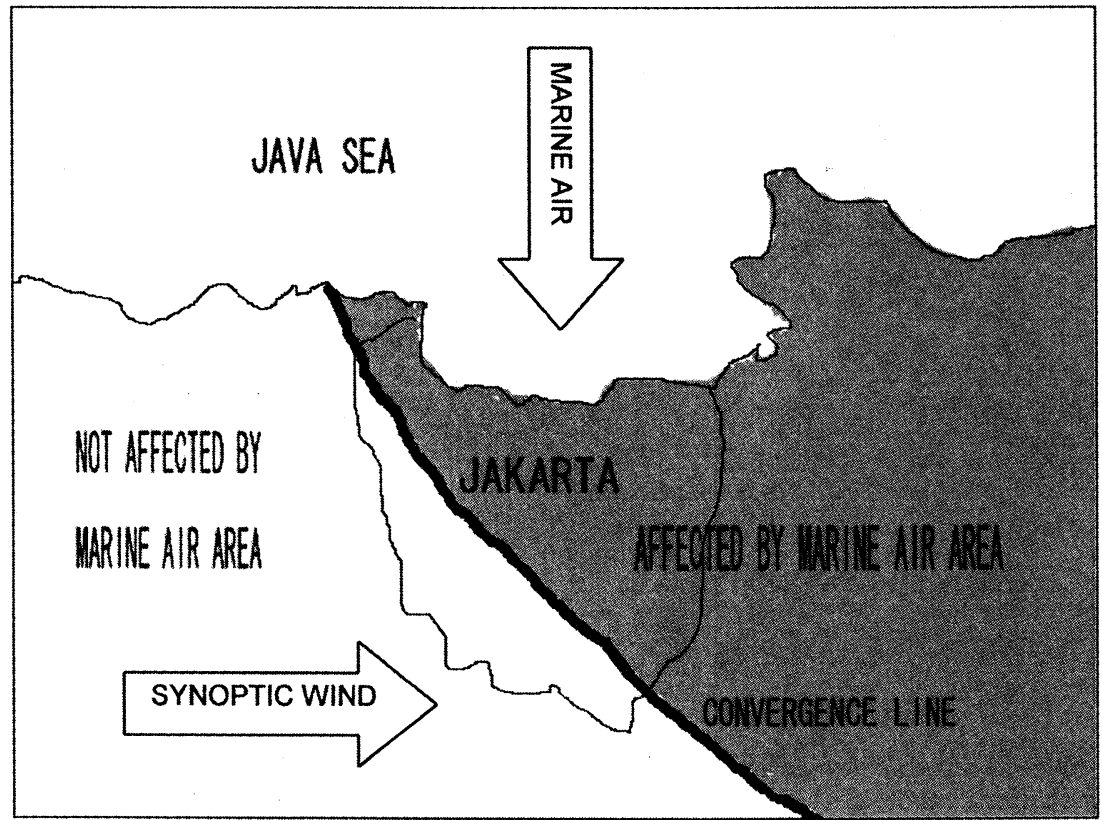

Fig. 9 Jakarta area have 2 region which are be separated by a convergence line (a convection line), the eastern part that be affected by marine air and the western part that not be affected. 
In Fig. $8 \mathrm{a}\left(\right.$ at $106.7^{0} \mathrm{E}, 6.2^{\circ} \mathrm{S}$ ) and Fig. $8 \mathrm{~b}\left(\right.$ at $106.8^{\circ} \mathrm{E}, 6.3^{\circ} \mathrm{S}$ ), the profile showed typical temperature profile, and sea breeze did not show its direct influence. But in Fig. $8 \mathrm{c}$ (at $106.8^{0} \mathrm{E}, 6.2^{\circ} \mathrm{S}$ ) and Fig. $8 \mathrm{~d}\left(\right.$ at $107^{\circ} \mathrm{E}$, $6.2^{0} \mathrm{~S}$ ), the wind affected by marine air. Thus, Jakarta area have 2 region which be separated by convection line, the eastern part that be affected by marine air and the western part that not be affected (Fig. 9).

\section{Characteristics of the formation of high pressure system to the northeast Jakarta.}

High-pressure system tends to be formed to the northeast of the Sunda street because of the topography (Fig. 10). Then this high-pressure system in turn generates dry stable layer over Jakarta at 2,000-4,000 m height and may suppress vertical diffusion of pollutants over Jakarta.

The pressure system at northwest Jakarta at 4 March 2001 occurs at 1000 LST - 1800 LST. Calculated skew T plots at Jakarta city at 4 Mar 2001, 1200 LST was plotted in figure 11b. Cross sectional plot of potential temperature $\left({ }^{0} \mathrm{~K}\right)$ and wind vectors along the line C-D and E-F (Fig. 10b) this area at 4 Mar 1200 LST was plotted in figure 12. In mountain area, wind direction was affected by a mountain wave.
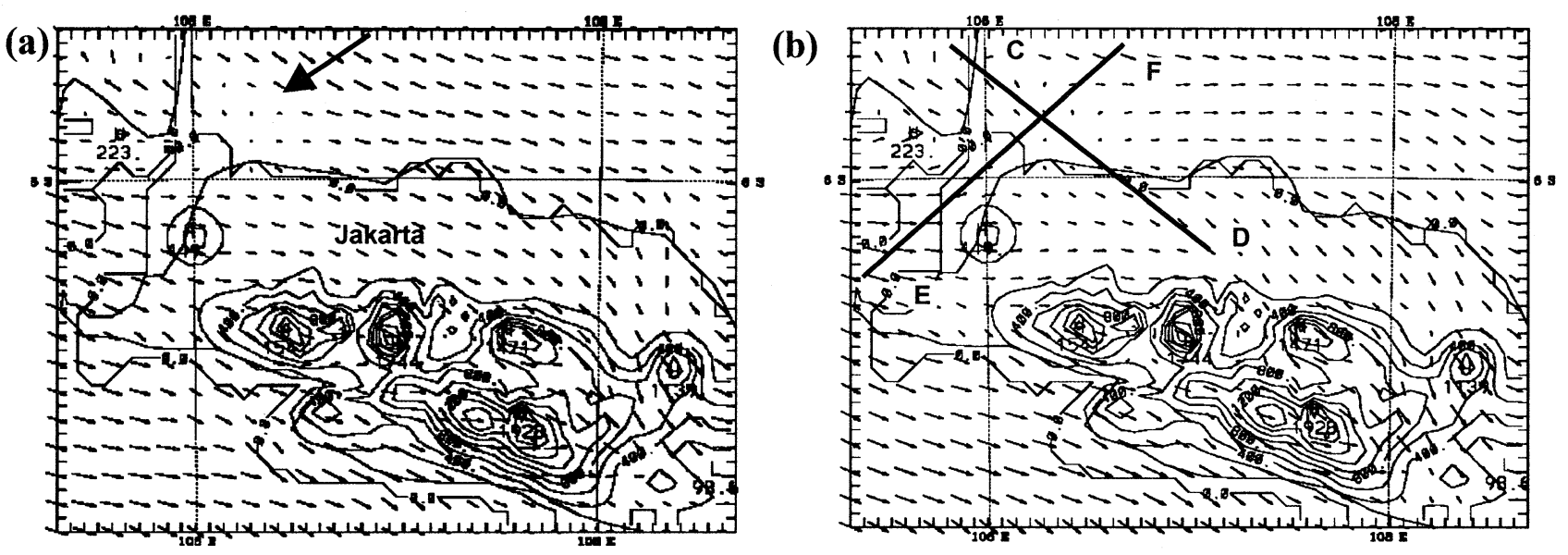

Fig.10. Predicted near-surface wind over western Java area on 4 Mar 2001. Contour shows terrain height interval of 200 m. (a) at 1200 LST. Arrow shows high pressure area. (b) at 1600 LST.
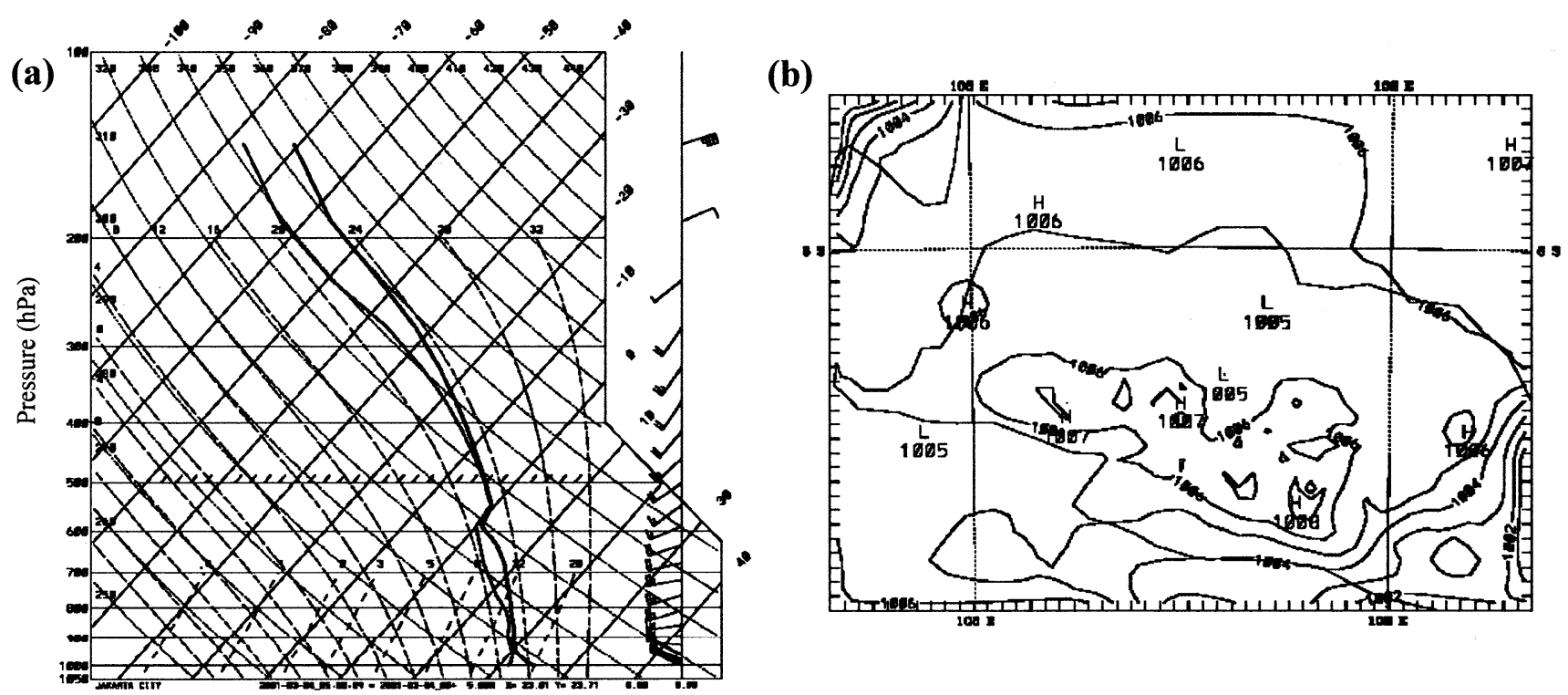

Fig.11. (a) Calculated skew T plots at Jakarta city at 4 Mar 2001, 1200 LST, (b) Calculated sea level pressure (in milibar) in domain 1 at 4 Mar 2001, 1200 LST. 

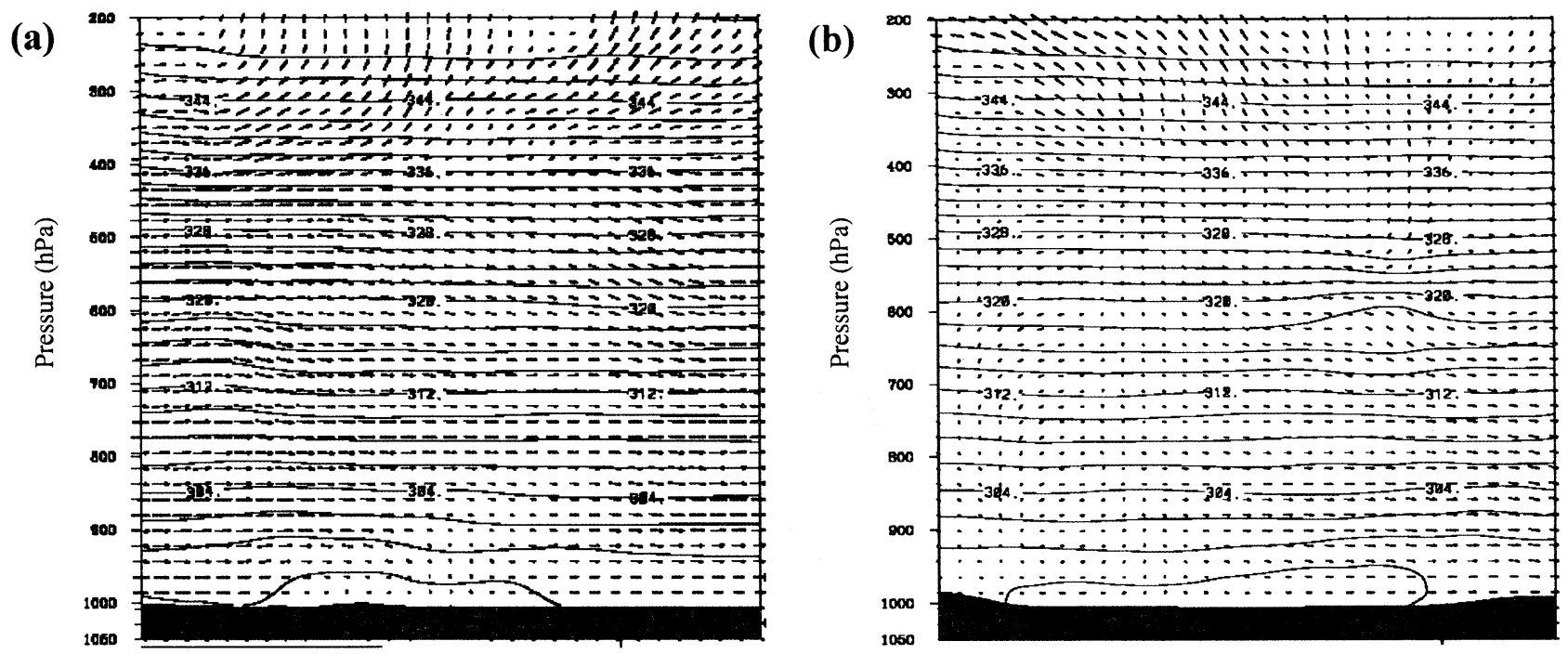

Fig.12. Cross sectional plot of potential temperature $\left({ }^{0} \mathrm{~K}\right)$ and wind vectors in high pressure area at 4 Mar 2001,1200 LST along the (a) line C-D and (b) line E-F (see Fig. 10b)

\section{Conclusion}

In conclusion, during 4-9 March 2001, the quite strong sea breeze developed on 5 and 6 March. In this season, Jakarta area is divided into two regions which are be separated by a convergence line (a convection line); there are the eastern part that be affected by marine air and the western part that not be affected. On March 6, 2001, at 1300 LST, the sea breeze penetrated to around $20 \mathrm{~km}$ from the coast of Jakarta. In this season, over Java area a synoptic scale convergence line is formed by WSW and NW winds. This synoptic WSW wind blowing over Java tends to prohibit inlandward advancement of the sea breeze. Depth of the sea breeze, on 6 Mar 2001 at 1200,1300,1400, and 1500 LST was $0.5,0.8,0,4$, and 0,2 km, respectively; because of subsidence behind the convergence line by the synoptic WSW wind and the sea breeze from Java sea, upper part of the sea breeze layer was warmed after 1500 LST and thus the depth of the sea breeze was suppressed. Predicted near-surface wind at 4-9 March 2001 appears dominantly with westerly wind. In mountain area, wind direction was affected by a mountain wave. High-pressure system tends to be formed to the northeast of the Sunda street because of the topography. Then this high-pressure system in turn generates dry stable layer over Jakarta at 2,000-4,000 m height and may suppress vertical diffusion of pollutants over Jakarta.

\section{References}

Dudhia J and Gill D (2003), PSU/NCAR Mesoscale Modeling System Tutorial Class Notes and User's Guide: MM5 Modeling System Version 3, Mesoscale and Microscale Meteorology Division, National Center for Atmospheric Research.

Hadi, T.W., T. Horinouchi, T. Tsuda, H. Hashiguchi, S. Fukao (2002), Sea Breeze Circulation over Jakarta, Indonesia: A Climatology Based on Boundary Layer Radar Observations, Monthly Weather Review, 130, 21532166.

Kitada T., Okamura K, and Tanaka S (1998) Effect of Topography and Urbanization on Local Winds and Thermal Environment in the Nohbi Plain, Coastal Region of Central Japan: A Numerical Analysis by Mesoscale Meteorological Model, Journal of Applied Meteorology, 37, 1026-1046.

Regmi R.P., Kurata G., and Kitada T. (2003) Numerical Simulation of Late Wintertime Local Flows in Kathmandu Valley, Nepal: Implication for Air Pollution Transport, Journal of Applied Meteorology, 42, 389402.

Simpson, J. E. (1994), Sea Breeze and Local Wind, Cambridge University Press, 234 pp. 